\title{
STRATEGI GURU DALAM PENGELOLAAN KELAS PADA PEMBELAJARAN PENDIDIKAN AGAMA ISLAM DI SMP NEGERI 39 BULUKUMBA
}

\author{
Andi Muhammad Asbar \\ STAI Al-Gazali Bulukumba, Sulawesi Selatan, Indonesia \\ Email: andimuhammadasbar@gmail.com
}

\begin{abstract}
Abstrak
Penelitian ini memiliki tujuan untuk mendeskripsikan strategi guru dalam pengelolaan kelas pada pembelajaran pendidikan agama Islam di SMP Negeri 39 Bulukumba. Penelitian ini tergolong sebagai penelitian kualitatif. Sumber data dalam penelitian ini adalah sumber data primer dan sumber data sekunder. Metode pengumpulan data dengan cara observasi, wawancara dan dokumentasi. Instrumen penelitian ini adalah peneliti sebagai instrumen kunci dengan menggunakan panduan observasi, pedoman wawancara dan format catatan dokumentasi.

Hasil penelitian yang ditemukan oleh peneliti adalah antara lain: 1) Strategi pengelolaan kelas yang dilakukan oleh guru SMP Negeri 39 Bulukumba dalam melaksanakan pembelajaran yang efektif, efisien dan menyenangkan, itu tergambarkan dalam pengelolaan administrasi kelas, pengelolaan operatif kelas, pengaturan ruang kelas, dan strategi pembelajaran. Kerjasama antara sekolah, guru dan siswa atau peserta didik, menjadi perhatian penting untuk ditingkatkan dalam meramu strategi pembelajaran di kelas khususnya, keaktifan dari Guru PAI SMP Negeri 39 Bulukumba tersebut. Dari penelitian ini, dapat dikatakan bahwa strategi pengelolaan kelas telah berjalan dengan baik, hanya saja komitmen bersama dilingkungan sekolah diperlukan untuk menjaga dan meningkatkan kualitas pembelajaran dapat tercipta di kelas; 2) Faktor pendukung dari strategi pengelolaan kelas dalam pembelajaran PAI di SMP Negeri 39 Bulukumba, antara lain; a. Kurikulum, hal ini penting menyangkut pelaksanaan pembelajaran yang sesuai dengan kurikulum nasional. dan b. Guru PAI, faktor guru disini sangat erat dengan kompetensi yang dimilikinya serta komitmen dalam menciptakan kondisi kelas yang baik. Sedangkan faktor penghambat dating dari guru sendiri, peserta didik dan fasilitas. Artinya bahwa hambatan pasti akan ada ditemui oleh guru, makanya dibutuhkan menanganan untuk mengantisipasi atau mengatasi hal tersebut; dan 3) Upaya yang dilakukan, yakni: a. Penguatan kompetensi guru PAI; b. Melakukan kontrak pembelajaran dalam kelas. Hal ini penting untuk mengatur peserta didik dan guru itu sendiri, yang disepakati dan dijalankan secara konsisten agar tercipta kelas yang efektif serta tercipta suasana kelas yang kondusif dan mendukung pembelajaran disekolah utamanya dalam pembelajaran PAI.

Keywords: Strategi Pengelolaan Kelas, Pendidikan Agama Islam
\end{abstract}

Jurnal Ilmiah Al QALAM, Vol. 12, No. 1, Januari-Juni 2018 
Andi Muhammad Asbar: Strategi Guru dalam Pengelolaan Kelas pada Pembelajaran Pendidikan Agama Islam di Smp Negeri 39 Bulukumba

\section{A. Pendahuluan}

Kebutuhan akan pendidikan ${ }^{111}$ merupakan hal yang tidak bisa dipungkiri, bahkan semua itu merupakan hak semua warga Negara dan kewajiban mendasar untuk dituntut oleh manusia yakni manusia yang memiliki pengetahuan. Jika melihat Undang-undang RI Nomor 20 Tahun 2003 tentang Sistem Pendidikan Nasional yang dimuat pada pasal 3 tentang tujuan pendidikan nasional adalah untuk mengembangkan potensi siswa agar menjadi manusia yang beriman dan bertakwa kepada Tuhan Yang Maha Esa, berakhlak mulia, sehat, berilmu, cakap, kreatif, mandiri dan menjadi warga Negara yang demokratis serta bertanggung jawab. ${ }^{112}$

Rahman Getteng mengatakan bahwa tujuan pendidikan berusaha membentuk pribadi berkualitas baik jasmani maupun rohani. Dengan demikian seorang guru dalam pendidikan mempunyai peran strategis dalam meningkatkan mutu pendidikan nasional. ${ }^{113}$ Di sisi lain tanggung jawab guru juga sangat berat, karena selain bertanggung jawab terhadap pembentukan pribadi anak yang sesuai dengan ajaran Islam, ia juga bertanggung jawab terhadap Allah swt.

Pendidikan pada hakikatnya merupakan suatu upaya mewariskan nilai ${ }^{114}$, yang akan menjadi penolong dan penentu umat manusia dalam menjalani kehidupan, sekaligus untuk memperbaiki nasib dan peradaban umat

${ }^{111}$ Pendidikan merupakan salah satu unsur dari aspek sosial budaya yang berperan sangat strategis dalam pembinaan suatu keluarga, masyarakat atau bangsa. Kestrategisan peranan ini pada intinya merupakan suatu ikhtiar yang dilaksanakan secara sadar, sistematis, terarah dan terpadu untuk memanusiakan siswa dan menjadikan mereka khalifah di muka bumi. Lihat Nurcholish Madjid, Masyarakat Religius (Cet. III; Jakarta: Paramadina, 2005), h. 114-116.

${ }^{112}$ Undang-Undang Republik Indonesia No. 20 Tahun 2003 tentang Sistem Pendidikan Nasional (Cet. I; Jakarta: Sinar Grafika, 2003), h. 5-6.

${ }^{113}$ Abd Rahman Getteng, Menuju Guru yang Profesional dan Beretika (Cet. III; Yogyakarta: Graha Guru, 2008), h. 97.

${ }^{114}$ Ada 2 (dua) hal yang muncul dari persoalan nilai, yakni pertama, kesadaran dan pemahaman terhadap nilai dan kedua, kesanggupan melaksanakan nilai. Idealnya kedua hal tersebut harus sinkron; baca Umar Tirtarahardja dan S. L. La Sulo, Pengantar Pendidikan Edisi Revisi (Cet. II; Jakarta: Rineka Cipta, 2005), h. 22.

Jurnal Ilmiah Al QALAM, Vol. 12, No. 1, Januari-Juni 2018 
Andi Muhammad Asbar: Strategi Guru dalam Pengelolaan Kelas pada Pembelajaran Pendidikan Agama Islam di Smp Negeri 39 Bulukumba

manusia. Maju mundurnya atau baik buruknya peradaban suatu masyarakat, suatu bangsa, akan ditentukan bagaimana pendidikan yang dijalani oleh masyarakat bangsa tersebut.

Pendidikan tidak sekedar mentransfer ilmu pengetahuan kepada peserta didik, tetapi lebih dari itu, yakni mentransfer nilai. Selain itu, pendidikan juga merupakan kerja budaya yang menuntut peserta didik untuk selalu mengembangkan potensi dan daya kreativitas yang dimilikinya agar tetap survive dalam hidup.

Sedangkan, dalam konteks pendidikan Islam, maka penekanannya adalah pada aspek keserasian dan keseimbangan hidup manusia antara jasmani dan rohani, jiwa dan raga atau keseimbangan antara urusan duniawi dan ukhrawi. ${ }^{115}$ Semua manusia memperoleh porsi yang sama dalam pandangan Islam dalam kewajiban untuk menuntut ilmu pendidikan. Bukan hanya pengetahuan yang terkait urusan ukhrawi saja yang ditekankan oleh Islam, melainkan pengetahuan yang bersentuhan dengan urusan duniawi.

Pendidikan Islam adalah proses mentransformasi nilai-nilai keislaman yang merupakan kandungan hikmah yang terlahir dari al-Qur' an dan al-Sunnah. Mengingat pentingnya pendidikan, Islam menempatkan pendidikan pada kedudukan yang penting dan tinggi dalam doktrin Islam. Hal ini bisa dilihat dalam al-Qur'an dan Hadis yang banyak bagi kehidupan umat Islam sebagai hamba. ${ }^{116}$

Di antaranya dalam Qs. al-Zariyat/51: 56.

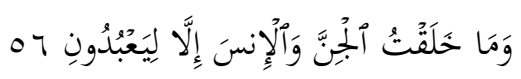

${ }^{115}$ Khaeruddin, Ilmu Pendidikan Islam: Mendesain Insan yang Hakiki dan Mengintip dalam Sejarahnya (Cet. II; Makassar: Yayasan Pendidikan Fatiya, 2004), h. 8 .

${ }^{116}$ Hanun Asrohah, Sejarah Pendidikan Islam (Cet. I; Jakarta: Logos Wacana Ilmu, 1999), h. 2.

Jurnal Ilmiah Al QALAM, Vol. 12, No. 1, Januari-Juni 2018 
Andi Muhammad Asbar: Strategi Guru dalam Pengelolaan Kelas pada Pembelajaran Pendidikan Agama Islam di Smp Negeri 39 Bulukumba

Terjemahnya: Aku tidak menciptakan jin dan manusia melainkan supaya mereka mengabdi kepada-Ku. ${ }^{117}$

M. Quraish Shihab menguraikan bahwa Allah menciptakan manusia agar menjadikan tujuan akhirnya atau hasil segala aktivitasnya sebagai pengabdian/ibadah kepada Allah swt. Dalam status sebagai khalifah, manusia hidup mendapat tugas untuk memakmurkan dunia ini sesuai dengan konsep yang ditetapkan oleh allah. ${ }^{118}$

Jika dicermati, ayat ayat tersebut menjelaskan urgensi makna pendidikan bagi manusia. Manusia sebagai khalifah allah diberi beban yang sangat berat. Tugas tersebut dapat dilaksanakan dengan baik jika manusia dibekali dengan pengetahuan, keterampilan, dan kepribadian luhur sesuai dengan petunjuk Allah. Hal tersebut hanya mampu terealisasi melalui proses pendidikan.

Pendidikan Agama Islam sebagai mata pelajaran di sekolah mempunyai sasaran pada peserta didik yang sedang dalam pertumbuhan dan perkembangan dan senantiasa mengadakan interaksi sosial dengan anggota masyarakat yang lainnya. Hal ini sangat penting karena Pendidikan Agama Islam adalah suatu usaha yang sistematis untuk menyelamatkan peserta didik dari pengaruh negatif yang mengarah kepada penyimpangan terhadap tujuan hidup yang sebenarnya, yaitu untuk mengabdi kepada Allah swt.

Pendidikan Agama Islam bukan merupakan materi tambahan di sekolah umum, Pendidikan agama memiliki kekuatan hukum yang mengikat yang harus dilaksanakan dalam jenjang pendidikan. Dalam UU RI Tahun 2003 tentang Sistem Pendidikan Nasional pada Bab V Pasal 12 ayat 1 dikatakan bahwa setiap peserta didik pada setiap satuan pendidikan berhak mendapatkan pendidikan

${ }^{117}$ Departemen Agama RI, al-Qur'anul Karim Terjemahnya dan Tajwid Berwarna Disertai Tafsir Ringkas Ibnu Katsir (Jakarta: Jabal Raudhotul Jannah, 2009), h. 523.

${ }^{118}$ M. Quraish Shihab, Membumikan al-Qur'an: Fungsi dan Peran Wahyu dalam Kehidupan Masyarakat (Bandung: Mizan, 1992), h. 172.

Jurnal Ilmiah Al QALAM, Vol. 12, No. 1, Januari-Juni 2018 
Andi Muhammad Asbar: Strategi Guru dalam Pengelolaan Kelas pada Pembelajaran Pendidikan Agama Islam di Smp Negeri 39 Bulukumba

agama sesuai dengan agama yang dianutnya dan diajarkan oleh pendidik yang seagama. ${ }^{119}$

Pembaharuan dalam dunia pendidikan saat ini memberi pengaruh besar terhadap persiapan dan cara mengajar seorang guru serta mempengaruhi persiapan dan kondisi belajar siswa di kelas, metode mengajar yang berbeda memberikan pengaruh terhadap suasana belajar di dalam kelas. Oleh karena itu guru perlu terampil dalam mengelola kelas.

Kemampuan seorang guru dalam pengelolaan kelas, memiliki peranan yang sangat sentral, baik sebagai perencana, pelaksana, maupun evaluator pembelajaran. Hal ini harus dipahami bahwa pendukung utama tercapainya tujuan pembelajaran sebagai media pertemuan segala komponen pendidikan. Pengelolaan kelas merupakan tugas utama guru dan wali kelas dalam menciptakan suasana kelas yang memungkinkan terjadinya interaksi pembelajaran semaksimal mungkin, meningkatkan, memperbaiki belajar siswa agar terlibat dalam kegiatan belajar mengajar dan lebih mudah dalam menerima pelajaran.

Mata pelajaran Pendidikan Agama Islam di Sekolah Dasar maupun di Sekolah Menengah memiliki tujuan dan fungsi berbeda dari setiap komponen materi yang dipelajari oleh siswa. Guru pendidikan agama Islam harus mampu memilih strategi yang tepat untuk pembelajaran dan mampu mengelola kelas dalam proses pembelajaran di sekolah, sehingga prestasi yang dihasilkan memungkinkan dapat membantu siswa dalam mencapai suatu kemudahan, kecepatan mencapai kebiasaan, dan kesenangan murid dalam mempelajari Islam untuk dijadikan pedoman dan petunjuk hidup dalam kehidupan siswa.

Mata pelajaran Pendidikan Agama Islam hanya diajarkan selama 2 (dua) jam di SMP Negeri 39 Bulukumba. Dengan waktu sangat minim dan komponen materi pelajaran Pendidikan Agama Islam yang relatif banyak, menjadi masalah umum di setiap sekolah utamanya guru PAI di sekolah tersebut.

${ }^{119}$ Undang-Undang Republik Indonesia No. 20 Tahun 2003 tentang Sistem Pendidikan Nasional, h. 10.

Jurnal Ilmiah Al QALAM, Vol. 12, No. 1, Januari-Juni 2018 
Andi Muhammad Asbar: Strategi Guru dalam Pengelolaan Kelas pada Pembelajaran Pendidikan Agama Islam di Smp Negeri 39 Bulukumba

Selain itu guru dituntut untuk membuat perencanaan pembelajaran dengan matang dan efektif dengan durasi yang terbilang sedikit. Hal lain yang menjadi masalah dalam proses belajar mengajar di kelas sering ditemui sikap atau tingkah laku siswa yang dapat mengganggu selama kegiatan pembelajaran berlangsung. Hal ini dikhawatirkan dapat mempengaruhi keberhasilan proses pembelajaran.

Untuk mencegah timbulnya tingkah laku-tingkah laku siswa yang mengganggu jalannya kegiatan belajar mengajar, guru berusaha mendayagunakan potensi kelas, memfokuskan perhatian kepada peserta didik, memahami mereka secara individu dan memberi pelayanan-pelayanan tertentu yang merupakan wujud dukungan dari warga sekolah.

Berdasarkan observasi awal peneliti dengan beberapa guru pendidikan agama Islam di SMP Negeri 39 Bulukumba, memberikan keterangan bahwa mereka menggunakan strategi dalam pengelolaan kelas. Strategi diperlukan guna membantu guru untuk memudahkan pembelajaran serta siswa juga dengan mudah memahami materi yang disampaikan dalam setiap pembelajaran. Namun, guru juga mengalami kendala atau hambatan dalam pembelajaran.

Kenyataan inilah yang mendorong peneliti untuk melihat strategi guru pendidikan agama Islam pengelolaan kelas di sekolah tersebut. Hal demikian menurut peneliti perlu dikaji lebih mendalam, sehingga akan dapat menambah khasanah keilmuan bagi guru terutama guru Pendidikan Agama Islam itu sendiri.

\section{B. Kajian Teori}

\section{Strategi Pengelolaan Kelas}

Dalam dunia pendidikan, strategi diartikan sebagai perencanaan yang berisi tentang rangkaian kegiatan yang didesain untuk mencapai tujuan pendidikan tertentu. Sedangkan untuk mengimplementasikan rencana yang sudah disusun dalam kegiatan nyata agar tujuan yang telah disusun tercapai secara optimal adalah dinamakan

Jurnal Ilmiah Al QALAM, Vol. 12, No. 1, Januari-Juni 2018 
Andi Muhammad Asbar: Strategi Guru dalam Pengelolaan Kelas pada Pembelajaran Pendidikan Agama Islam di Smp Negeri 39 Bulukumba

dengan metode. Strategi menunjuk pada sebuah perencanaan untuk mencapai sesuatu, sedangkan metode adalah cara yang dapat digunakan untuk melaksanakan strategi. ${ }^{120}$ Mengacu pada konteks belajar mengajar bahwa strategi dalam penelitian ini adalah tehnik atau siasat yang digunakan guru dan diperagakan oleh guru dan siswa dalam berbagai peristiwa pembelajaran untuk mewujudkan tujuan pembelajaran agar lebih efektif dan efisien.

Sedangkan, "pengelolaan kelas" terdiri dari dua kata yaitu pengelolaan dan kelas. Pengelolaan merupakan terjemahan dari kata "management". Dalam kamus umum bahasa Indonesia disebutkan bahwa pengelolaan adalah penyelenggaraan atau pengurusan agar sesuatu yang dikelola dapat berjalan dengan lancar, efektif dan efisien. ${ }^{121}$ Dengan demikian pengelolaan dapat diartikan bahwa kemampuan atau keterampilan seseorang dalam melakukan tindakan-tindakan melalui proses kegiatan-kegiatan orang lain dalam rangka meraih suatu pencapaian hasil yang dapat berfungsi sebagai sumber penyempurnaan dan peningkatan keterampilan selanjutnya.

Kegiatan pengelolaan kelas dapat diartikan sebagai kemampuan guru atau wali kelas dalam mendayagunakan potensi kelas berupa pemberian kesempatan yang seluas-luasnya pada setiap personal untuk melakukan kegiatan-kegiatan yang kreatif dan terarah, sehingga waktu dan dana yang tersedia dapat dimanfaatkan secara efisien untuk melakukan kegiatan kelas yang berkaitan dengan kurikulum dan perkembangan murid. ${ }^{122}$

\footnotetext{
${ }^{120}$ Wina Sanjaya, Strategi Pembelajaran Berorientasi Standar Proses Pendidikan, (Jakarta: Kencana, 2007), h. 126.

${ }^{121}$ Suharsimi Arikunto, Pengelolaan Kelas dan Siswa, Sebuah Pendekatan Evaluatif, (Jakarta: Rajawali, 1992), h.7.

${ }^{122}$ Syaiful Bahri Djamarah dan Aswan Zain, Strategi Belajar Mengajar, (Jakarta: PT. Rineka Cipta, 2006), h. 177.
}

Jurnal Ilmiah Al QALAM, Vol. 12, No. 1, Januari-Juni 2018 
Andi Muhammad Asbar: Strategi Guru dalam Pengelolaan Kelas pada Pembelajaran Pendidikan Agama Islam di Smp Negeri 39 Bulukumba

\section{Tujuan dan Fungsi Pengelolaan Kelas}

Secara umum tujuan pengelolaan kelas menurut Sudirman N adalah penyediaan fasilitas bagi bermacam-macam kegiatan belajar siswa dalam lingkungan sosial, emosional, dan intelektual dalam kelas. Fasilitas yang disediakan itu memungkinkan siswa belajar dan bekerja, terciptanya suasana social yang memberikan kepuasan, suasana disiplin, perkembangan intelektual, emosional dan sikap serta apresiasi pada siswa. ${ }^{123}$

Tujuan pengelolaan kelas menurut Suharsimi Arikunto adalah agar setiap anak di kelas itu dapat bekerja tertib sehingga tercapai tujuan pengajaran secara efektif dan efisien, sebagai indikator dari sebuah kelas yang tertib, adalah:

a. Setiap anak terus bekerja, tidak macet, artinya tidak ada anak yang berhenti karena tidak tahu akan tugas yang diberikan padanya.

b. Setiap anak harus melakukan pekerjaan tanpa mrmbuang waktu, artinya tiap anak akan bekerja secepatnya agar lekas menyelesaikan tugas yang diberikan kepadanya. ${ }^{124}$

Dari pengertian diatas dikemukakan bahwa pengelolaan kelas berkaitan erat dengan pengaturan kelas untuk mencapai tujuan pembelajaran. Hal ini merupakan tugas guru untuk menciptakan suasana yang dapat menimbulkan gairah belajar, meningkatkan prestasi belajar siswa, meningkatkan mutu pembelajaran dan lebih memungkinkan guru memberikan bimbingan terhadap siswa dalam belajar, sehingga diperlukan pengorganisasian kelas yang memadai.

Siswa juga harus mampu memimpin kelasnya sendiri sebagai kontrol dalam belajar mereka. Kerja sama dalam kelas akan tampak 178.

${ }^{123}$ Syaiful Bahri Djamarah dan Aswan Zain, Strategi Belajar Mengajar, h.

\footnotetext{
${ }^{124}$ Suharsimi Arikunto, Pengelolaan Kelas dan Siswa, Sebuah Pendekatan Evaluatif, h. 68 .
}

Jurnal Ilmiah Al QALAM, Vol. 12, No. 1, Januari-Juni 2018 
Andi Muhammad Asbar: Strategi Guru dalam Pengelolaan Kelas pada Pembelajaran Pendidikan Agama Islam di Smp Negeri 39 Bulukumba

dengan adanya kekompakan untuk semangat belajar.

\section{Prinsip-prinsip Pengelolaan Kelas}

Secara umum faktor-faktor yang mempengaruhi pengelolaan kelas dibagi menjadi dua golongan, yaitu: faktor intern siswa dan faktor ekstern siswa. Faktor intern siswa berhubungan dengan masalah emosi, pikiran dan perilaku siswa. Sedangkan, faktor ekstern siswa terkait dengan masalah suasana lingkungan belajar, penempatan siswa, pengelompokan siswa, jumlah siswa dan sebagainya. ${ }^{125}$

Oleh karena itu, untuk memperkecil masalah gangguan dalam pengelolaan kelas, perlu dikuasai oleh guru prinsip-prinsip pengelolaan kelas, yang meliputi:

a. Hangat dan Antusias.

Guru yang hangat dan akrab dengan anak didik selalu menunjukkan antusias pada tugasnya atau pada aktivitasnya akan berhasil dalam mengimplementasikan pengelolaan kelas.

b. Tantangan

Penggunaan kata-kata, tindakan, cara kerja atau bahan-bahan yang menantang akan meningkatkan gairah anak didik untuk belajar sehingga mengurangi kemungkinan munculnya tingkah laku yang menyimpang, selanjutnya akan menambah menarik perhatian anak didik dan dapat mengendalikan gairah belajar peserta didik.

c. Bervariasi

Penggunaan alat atau media, gaya mengajar guru, pola interaksi antara guru dan anak didik akan mengurangi munculnya gangguan, meningkatkan perhatian anak didik. Kevariasian dalam penggunaannya merupakan kunci untuk tercapainya pengelolaan kelas yang efektif dan menghindari kejenuhan.

\section{1.}

${ }^{125}$ Made Pidarta, Pengelolaan Kelas, (Surabaya: Usaha Nasional, 1970), h.

Jurnal Ilmiah Al QALAM, Vol. 12, No. 1, Januari-Juni 2018 
Andi Muhammad Asbar: Strategi Guru dalam Pengelolaan Kelas pada Pembelajaran Pendidikan Agama Islam di Smp Negeri 39 Bulukumba

d. Keluwesan

Keluwesan tingkah laku guru untuk mengubah strategi mengajarnya dapat mencegah kemungkinan munculnya gangguan anak didk serta menciptakan iklim belajar mengajar yang efektif. keluwesan pengajaran dapat mencegah munculnya gangguan seperti keributan, tidak ada perhatian, tidak mengerjakan tugas dan sebagainya.

e. Penekanan pada hal-hal yang positif Penekanan yang dilakukan guru tarhadap tingkah laku anak didik yang positif dari pada mengomeli tingkah laku yang negatif. Penekanan tersebut dapat dilakukan dengan pemberian penguatan positif, dn kesadaran guru untuk menghindari kesalahan yang dapat mengganggu jalannya proses belajar mengajar.

f. Penanaman disiplin diri

Anak didik dapat mengembangkan disiplin diri sendiri. Oleh karena itu, guru selalu mendorong anak didik untuk melaksanakan disiplin diri sendiri dan guru menjadi teladan mengenai pengendalian diri dan pelaksanaan tanggung jawab. ${ }^{126}$

Keakraban guru, pola interaksi, cara kerja yang menantang, kevariasian dalam pembelajaran, keluwesan tingkah laku guru untuk mengubah strategi mengajarnya, penekanan guru tarhadap tingkah laku siswa yang positif, dan keteladanan guru merupakan modal awal dalam penanaman disiplin diri pada siswa yang dapat mengurangi kemungkinan munculnya tingkah laku yang menyimpang, dan menambah menarik perhatian anak didik, Prinsip-prinsip pengelolaan kelas ini merupakan konsep-konsep yang harus diterapkan dalam proses belajar mengajar.

185.

${ }^{126}$ Syaiful Bahri Djamarah dan Aswan Zain, Strategi Belajar Mengajar, h.

Jurnal Ilmiah Al QALAM, Vol. 12, No. 1, Januari-Juni 2018 
Andi Muhammad Asbar: Strategi Guru dalam Pengelolaan Kelas pada Pembelajaran Pendidikan Agama Islam di Smp Negeri 39 Bulukumba

\section{Pendidikan Agama Islam}

Pendidikan agama Islam sebagaimana yang tertuang dalam GBPP PAI di sekolah umum, dijelaskan bahwa pendidikan agama Islam adalah upaya sadar dan terencana dalam menyiapkan peserta didik untuk mengenal, memahami, menghayati, hingga mengimani ajaran agama Islam, dibarengi dengan tuntutan untuk menghormati penganut agama lain dalam hubungannya dengan kerukunan antar umat beragama hingga terwujud kesatuan dan persatuan bangsa. ${ }^{127}$

Mata pelajaran Pendidikan Agama Islam secara keseluruhannya dalam lingkup al-Qur'an dan al-Hadis, keimanan, akhlak, fiqih, dan sejarah, sekaligus menggambarkan bahwa ruang lingkup pendidikan agama Islam mencakup perwujudan keserasian, keselarasan dan keseimbangan hubungan manusia dengan Allah swt. diri sendiri, sesama manusia, makhluk lainnya maupun lingkungannya. ${ }^{128}$ Jadi, Pendidikan Agama Islam merupakan usaha sadar yang dilakukan pendidik dalam rangka mempersiapkan peserta didik untuk meyakini, memahami, dan mengamalkan ajaran Islam melalui kegiatan bimbingan, pengajaran atau pelatihan yang telah ditentukan untuk mencapai tujuan yang telah ditetapkan.

Dari pengertian tersebut dapat ditemukan beberapa hal yang perlu diperhatikan dalam pembelajaran pendidikan agama islam, yaitu berikut ini :

a. Pendidikan Agama Islam sebagai usaha sadar, yakni suatu kegiatan bimbingan, pengajaran dan latihan yang dilakukan secara berencana dan sadar atas tujuan yang hendak dicapai.

${ }^{127}$ Muhaimin, Wacana Pengembangan Pendidikan Islam, (Yogyakarta: Pustaka Pelajar, 2003), h. 76.

${ }^{128}$ Abdul Majid dan Dian Andayani, Pendidikan Agama Islam Berbasis Kompetensi, (Bandung: PT Rosdakarya, 2005), h. 130.

Jurnal Ilmiah Al QALAM, Vol. 12, No. 1, Januari-Juni 2018 
Andi Muhammad Asbar: Strategi Guru dalam Pengelolaan Kelas pada Pembelajaran Pendidikan Agama Islam di Smp Negeri 39 Bulukumba

b. Peserta didik yang hendak disiapkan untuk mencapai tujuan, dalam arti ada yang dibimbing, diajari dan/atau dilatih dalam peningkatan keyakinan, pemahaman, penghayatan, dan pengamalan terhadap ajaran Islam.

c. Pendidikan atau Guru Pendidikan Agama Islam (GPAI) yang melakukan kegiatan bimbingan, pengajaran dan/atau pelatihan secara sadar terhadap peserta didiknya untuk mencapai tujuan pendidikan agama Islam.

d. Kegiatan (pembelajaran) Pendidikan Agama Islam diarahkan untuk meningkatkan keyakinan, pemahaman, penghayatan dan pengamalan ajaran agama Islam dari peserta didik, yang disamping untuk membentuk kesalehan pribadi, juga sekaligus untuk membentuk kesalehan sosial. ${ }^{129}$

Pendidikan Agama Islam menurut Direktorat Pembinaan Pendidikan Agama Islam di Sekolah Umum Negeri adalah suatu usaha bimbingan dan asuhan terhadap anak diddik agar nantinya setelah selesai dari pendidikan seseorang dapat memahami apa yang terkandung di dalam Islam secara keseluruhan, menghayati makna dan maksud serta tujuannya dan pada akhirnya dapat mengamalkannya serta menjadikan ajaran-ajaran agama Islam yang telah dianutnya itu sebagai pandangan hidupnya sehingga dapat mendatangkan keselamatan dunia dan akhirat kelak. ${ }^{130}$

Sedangkan yang dimaksud dengan Pendidikan Agama Islam yaitu upaya sadar dan terencana dalam menyiapkan peserta didik untuk mengenal, memahami, menghayati hingga mengimani, bertaqwa, dan berakhlak mulia dalam mengamalkan ajaran agama Islam dari alQuran dan Hadis, melalui kegiatan bimbingan, pengajaran,

\footnotetext{
${ }^{129}$ Muhaimin, dkk, Paradigma Pendidikan Islam, (Cet. V; Bandung: PT. Rosdakarya, 2012), h. 76.

${ }^{130}$ Zakiyah Daradjat, Ilmu Pendidikan Islam, (Jakarta: PT. Bumi Aksara, 2009), h.88
}

Jurnal Ilmiah Al QALAM, Vol. 12, No. 1, Januari-Juni 2018 
Andi Muhammad Asbar: Strategi Guru dalam Pengelolaan Kelas pada Pembelajaran Pendidikan Agama Islam di Smp Negeri 39 Bulukumba

latihan serta penggunaan pengalaman. ${ }^{131}$ Pembelajaran Pendidikan Agama Islam yang dimaksud dalam penelitian ini adalah pembelajaran bidang studi Pendidikan Agama Islam yang harus dialami oleh peserta didik muslim dalam menyelesaikan pendidikannya pada tingkatan tertentu agar mereka mengetahui dan memahami ajaran-ajaran dalam agama Islam.

\section{Metode Penelitian}

Jenis penelitian ini tergolong sebagai penelitian kualitatif. Dikatakan sebagai penelitian kualitatif, sebab penelitian ini bermaksud untuk memahami fenomena tentang apa yang dialami subyek penelitian, misalnya perilaku, persepsi, motivasi, tindakan dan lain-lain secara holistik (utuh), dan dengan cara deskripsi dalam bentuk kata-kata dan bahasa, pada suatu konteks khusus yang alamiah, dan dengan memanfaatkan berbagai metode ilmiah. ${ }^{132}$ Sedangkan, lokasi penelitian ini dilakukan di SMP Negeri 39 Bulukumba, beralamat di jalan poros Kelurahan Palampang, Kecamatan Rilau Ale Kabupaten Bulukumba

Adapun yang menjadi fokus penelitian ini adalah strategi guru dalam pengelolaan kelas pada pembelajaran pendidikan agama Islam di SMP Negeri 39 Bulukumba, yang dilihat dari beberapa perspektif meliputi: pertama, strategi guru dalam pengelolaan kelas pada pembelajaran pendidikan agama Islam di SMP Negeri 39 Bulukumba; kedua, faktor pendukung dan penghambat strategi guru dalam pengelolaan kelas pada pembelajaran pendidikan agama Islam di SMP Negeri 39 Bulukumba; dan ketiga, upaya guru dalam mengatasi hambatan strategi guru dalam pengelolaan kelas pada pembelajaran pendidikan agama Islam di SMP Negeri 39 Bulukumba.

Sedangkan, sumber data dalam penelitian ini terbagi menjadi dua, yaitu: pertama, sumber data primer dalam penelitian ini adalah sumber data yang

${ }^{131}$ Departemen Pendidikan Nasional, Standar Kompetensi Mata Pelajaran Pendidikan Agama Islam SMP dan MTS, (Jakarta: Pusat Kurikulum, Balitbang Depdiknas, 2003), h. 7.

${ }^{132}$ Lihat Lexy J. Moleong, Metodologi Penelitian Kualitatif (Cet. XXVIII; Bandung: Remaja Rosdakarya, 2006), h. 6.

Jurnal Ilmiah Al QALAM, Vol. 12, No. 1, Januari-Juni 2018 
Andi Muhammad Asbar: Strategi Guru dalam Pengelolaan Kelas pada Pembelajaran Pendidikan Agama Islam di Smp Negeri 39 Bulukumba

diperoleh langsung dari informan di lapangan sesuai dengan permasalahan yang dibahas dalam penelitian ini. Data tersebut bersumber dari hasil wawancara peneliti dengan guru materi PAI, perwakilan peserta didik dan pihak-pihak yang dianggap terkait dengan permasalahan penelitian ini. Dan kedua, Data Sekunder adalah sumber data tambahan di luar kata-kata dan tindakan yakni sumber data tertulis yang diperoleh dari dokumen-dokumen resmi, buku harian dan sebagainya atau catatan tentang adanya suatu peristiwa atau catatan yang jaraknya telah jauh dari sumber orisinil.

Analisis data adalah usaha untuk mencari dan menyusun secara sistematis catatan-catatan observasi, wawancara dan dokumentasi untuk meningkatkan pemahaman peneliti tentang kasus yang diteliti dan menyajikannya sebagai temuan. Analisis data dilakukan dalam upaya mencari makna. ${ }^{133}$

Dengan demikian, analisis pengolahan data yang peneliti lakukan adalah berawal dari observasi, kemudian dilakukan wawancara secara mendalam. Kemudian mereduksi data, dalam hal ini peneliti memilah dan memilih data mana yang dianggap relevan dan penting sesuai dengan fokus penelitian. Setelah itu, peneliti menyajikan hasil penelitian dengan menemukan temuan-temuan baru lalu dibandingkan dengan penelitian terdahulu. Sehingga dari sinilah peneliti membuat kesimpulan dan implikasi/saran sebagai bagian akhir dari penelitian ini.

\section{Hasil Penelitian dan Pembahasan}

\section{Strategi Guru dalam Pengelolaan Kelas pada Pembelajaran}

\section{Pendidikan Agama Islam di SMP Negeri 39 Bulukumba}

Guru di SMP Negeri 39 Bulukumba menuntut untuk profesional dalam melakukan proses pembelajaran dengan efektif, efisien dan menyenangkan. Untuk mencapai hal ini sekolah dan guru harus

${ }^{133}$ Noeng Muhajir, Metodologi Penelitian Kualitatif (Yogyakarta: Rake Sarasin, 1996), h. 67.

Jurnal Ilmiah Al QALAM, Vol. 12, No. 1, Januari-Juni 2018 
Andi Muhammad Asbar: Strategi Guru dalam Pengelolaan Kelas pada Pembelajaran Pendidikan Agama Islam di Smp Negeri 39 Bulukumba

merencanakan program-program yang nantinya akan dilaksanakan hingga berlangsung dengan baik, tanpa timbulnya masalah atau gangguan yang tidak diinginkan dalam pembelajaran. Kalaupun timbul masalah atau gangguan guru harus dengan bijak untuk mengatasi atau meminimalisir timbulnya masalah tersebut. Oleh karena itu, diperlukan strategi dalam mengelola kelas dalam rangka menciptakan dan mempertahankan kondisi kelas agar tetap kondusif untuk pembelajaran.

Peneliti menemukan ada 4 (empat) strategi guru yang digunakan dalam pengelolaan kelas dalam pembelajaran Pendidikan Agama Islam di SMP Negeri 39 Bulukumba, antara lain;

\section{a. Pengelolaan administrasi kelas}

Di bagian ini, peneliti menemukan beberapa hal yang menjadi temuan dalam penelitian ini. Guru Pendidikan Agama Islam di sekolah tersebut menguraikan beberapa hal yang menjadi pekerjaannya di kelas. Hal yang dimaksud, yakni; pertama guru membuat perencanaan kelas, setiap program yang direncanakan khususnya dalam pembelajaran pendidikan agama Islam, guru membuat rencana pelaksanaan pembelajaran (RPP) yang sistematis.

Kedua, pengarahan kelas dalam hal ini berkaitan dengan program-program yang sudah disusun dan disepakati antara guru dan siswa. Misalnya, membaca doa pada waktu awal jam pelajaran dan akhir jam pelajaran yang juga sudah diberikan arahan mengenai isi doanya. Peneliti melihat, setiap awal dan akhir jam pelajaran, siswa berdoa bersama yang dipimpin oleh guru atau siswa setiap akan memulai dan mengakhiri pelajaran di kelas. Siswa juga harus mengucapkan salam kepada guru yang mengajar. Dan ketiga adalah kontrol kelas. Guru melakukan kontrol tentang keberhasilan dan ketidakberhasilan setiap kegiatan. Kamaruddin, mengatakan bahwa absensi siswa yang hadir dan tidak hadir dalam kegiatan keagamaan adalah merupakan bentuk kontrol terhadap siswa dalam

Jurnal Ilmiah Al QALAM, Vol. 12, No. 1, Januari-Juni 2018 
Andi Muhammad Asbar: Strategi Guru dalam Pengelolaan Kelas pada Pembelajaran Pendidikan Agama Islam di Smp Negeri 39 Bulukumba

berpartisipasi mengikuti program kegiatan keagamaan. ${ }^{134}$

Aktivitas Baca Tulis Al-Qur'an, shalat dzuhur berjamaah diadakan pengabsenan pada kelas yang terkena giliran shalat berjama'ah, dan setiap hari senin setelah upacara diadakan pemanggilan bagi siswa yang tidak mengikuti tersebut. Sedangkan, kontrol terhadap kualitas pelaksanaan tugas murid pada kegiatan keagamaan ini sebagai bentuk evaluasi belum maksimal, hanya sebatas belajar dan latihan saja ketika kegiatan itu berlangsung.

\section{b. Pengelolaan operatif kelas}

Untuk mencapai tujuan dan keberhasilan belajar, kegiatan pembelajaran perlu ditunjang oleh kegiatan operatif.

\section{1) Perbekalan kelas}

Program kelas dan pembelajaran dapat berlangsung dengan efektif, bila digunakan media pengajaran yang memadai. Berdasarkan observasi yang dilihat, adanya papan tulis, kursi, bangku, dan sebagainya sudah memenuhi syarat untuk layak digunakan demi kelancaran pembelajaran. Selain itu, dalam ruang multi media pembelajaran disediakan oleh sekolah untuk menunjang pembelajaran. Dapat disimpulkan bahwa sarana yang disediakan masih belum maksimal, namun demikian guru tetap berusaha memanfaatkan perbekalan kelas berupa media pembelajaran.

\section{2) Pembinaan personal kelas}

Pembinaan personal kelas yang dilakukan di SMP Negeri 39 Bulukumba, salah satunya adalah dalam aspek penempatan siswa. Pengaturan ini dilakukan tergantung pada kebijakan wali kelas, tetapi tidak menutup kemungkinan guru yang mengajar

${ }^{134}$ Kamaruddin, Guru Pendidikan Agama Islam pada kelas IX/A-G di SMP Negeri 39 Bulukumba, Wawancara, Bulukumba, 07 Maret 2016.

Jurnal Ilmiah Al QALAM, Vol. 12, No. 1, Januari-Juni 2018 
Andi Muhammad Asbar: Strategi Guru dalam Pengelolaan Kelas pada Pembelajaran Pendidikan Agama Islam di Smp Negeri 39 Bulukumba

memindahkan posisi duduk siswa ketika jam pelajaran guru tertentu. Menurut Herlina sebagai guru agama dan wali kelas VIII/B menyatakan bahwa, tempat duduk siswa diatur menurut kebijakan wali kelas, namun beliau sendiri sebagai wali kelas memiliki ketentuan dan pertimbangan berikut: tinggi pendek badan, sehingga siswa yang kebetulan pendek/kecil bisa melihat ke papan tulis tanpa terhalangi teman yang tinggi badannya digunakannya sistem rooling, yaitu siswa perderet bangku secara bergiliran 1 bulan sekali pindah ke deretan sampingnya. Sehingga pandangan penglihatan siswa ke depan kelas ada keseimbangan pada tiap bangku. ${ }^{135}$

Dari pengaturan yang dibuat ini, pada sekolah ini dalam memposisikan tempat duduk siswa cukup baik, namun dasar pembinaannya masih belum terarah. Hal ini terlihat pada dasar pembinaan penempatan posisi duduk siswa yang hanya mempertimbangkan dari aspek fisik saja, belum mempertimbangkan intelegensi, bakat dan minat siswa.

\section{3) Kepemimpinan guru di kelas}

Peneliti menemukan bahwa guru PAI di SMP Negeri 39 Bulukumba dalam membimbing dan menggerakkan siswanya telah memberikan cara-cara dan motivasi yang tinggi kepada siswanya. Sehingga suasana religius di alami oleh siswa. Namun demikian dukungan dari guru-guru yang lain masih kurang maksimal, yang kurang memberikan pengaruh terhadap siswa. Sehingga guru PAI harus lebih baik lagi dalam memotivasi siswa.

\section{c. Pengaturan ruang kelas}

Peneliti melihat bahwa penataan ruang kelas di SMP Negeri 39 Bulukumba, cukup baik. Kelas merupakan fasilitas yang perlu

${ }^{135}$ Herlina, Guru Pendidikan Agama Islam pada kelas VIII/A-G di SMP Negeri 39 Bulukumba, Wawancara, Bulukumba, 15 Maret 2016.

Jurnal Ilmiah Al QALAM, Vol. 12, No. 1, Januari-Juni 2018 
Andi Muhammad Asbar: Strategi Guru dalam Pengelolaan Kelas pada Pembelajaran Pendidikan Agama Islam di Smp Negeri 39 Bulukumba

ditata dengan membuat kreasi lingkungan pembelajaran yang menyenangkan dan efisien, yaitu:

\section{1) Meja dan kursi}

Keadaan dan ukuran kursi dan meja guru yang ada cukup memadai bagi guru, yang dilengkapi dengan laci. Pengaturan meja guru dan siswa di dalam kelas sendiri, masih monoton pada bentuk tradisional, karena sulitnya pemindahan bangku dan tidak efisien untuk belajar kelompok, hanya efisien untuk belajar berpasangan.

\section{2) Papan tulis/Whiteboard}

Papan tulis yang ada disetiap kelas layak untuk digunakan, baik ukuran maupun warnanya, warnanya hitam yang dilengkapi tempat spidol dan penghapus.

\section{3) Struktur organisasi kelas}

Setiap kelas telah memiki perangkat kelas secara lengkap. Dari hasil observasi siswa membuat struktur kelas dengan bermacam-macam bentuk. Mulai dari yang sederhana berupa print out biasa hingga ada yang menggunakan kertas karton berwarna (manila). Hal ini tergantung pada kreatifitas siswa di kelas.

\section{d. Strategi pembelajaran.}

Di SMP Negeri 39 Bulukumba telah mempunyai rencana program sebagai suatu sasaran operasional bahwa melaksanakan proses pembelajaran untuk semua kelas dengan berbasis pendekatan pembelajaran aktif, diantaranya CTL dan PAKEM. Dalam pembelajaran PAI, telah dengan pendekatan PAKEM (Pembelajaran Aktif, Kreatif, Efektif dan efisien, menyenangkan) telah dilakukan oleh guru PAI juga. Tetapi tidak semua pembelajaran PAI menggunakan metode CTL.

Penyampaian materi yang disajikan dengan sistematis, dengan mendahulukan materi daripada praktik, materi disesuaikan 
Andi Muhammad Asbar: Strategi Guru dalam Pengelolaan Kelas pada Pembelajaran Pendidikan Agama Islam di Smp Negeri 39 Bulukumba

dengan kompetensi dasar (KD) yang ingin dicapai. Strategi dan metode yang digunakan tanya jawab dan ceramah dengan membawa siswa untuk menemukan sendiri apa yang harus ia pelajari. Penilaian diperoleh dari proses kelompok, keaktifan dan individu yang dilakukan setelah materi benar-benar dikuasai oleh siswa.

\section{Faktor Pendukung dan Penghambat dalam Mengelola Kelas pada Pembelajaran Pendidikan Agama Islam di SMP Negeri 39 Bulukumba}

Faktor pendukung pembelajaran Pendidikan Agama Islam dari sebuah pelaksanaan strategi pengelolaan kelas di SMP Negeri 39 Bulukumba, yakni: pertama, kurikulum yang digunakan di sekolah sangat besar pengaruhnya terhadap aktifitas kelas dalam mewujudkan proses belajar mengajar yang berdaya guna bagi pembentukan pribadi siswa. Sekolah yang kurikulumnya dirancang secara tradisional akan mengakibatkan aktifitas kelas akan berlangsung secara statis. Sedangkan, sekolah yang diselenggarakan dengan kurikulum modern pada dasarnya akan mampu menyelenggarakan kelas yang bersifat dinamis. Kurikulum yang digunakan di SMP Negeri 39 Bulukumba yaitu kurikulum tingkat satuan pendidikan (KTSP), yang mengacu terhadap kurikulum nasional.

Kedua, guru PAI. Program kelas tidak akan berarti bilamana tidak diwujudkan menjadi kegiatan. Untuk itu peranan guru sangat menentukan karena kedudukannya sebagai pemimpin diantara siswa di kelas. Setiap guru harus memahami fungsinya karena sangat besar pengaruhnya terhadap cara bertindak dan berbuat dalam menunaikan pekerjaan sehari-hari di kelas dan di masyarakat. Guru yang memahami kedudukan dan fungsinya sebagai pendidik profesional, selalu terdorong untuk tumbuh dan berkembang sebagai perwujudan perasaan dan sikap tidak puas terhadap pendidikan. Persiapan yang harus diikuti, sejalan dengan ilmu pengetahuan dan teknologi.

Sedangkan, faktor penghambat antara lain; pertama, guru sendiri

Jurnal Ilmiah Al QALAM, Vol. 12, No. 1, Januari-Juni 2018 
Andi Muhammad Asbar: Strategi Guru dalam Pengelolaan Kelas pada Pembelajaran Pendidikan Agama Islam di Smp Negeri 39 Bulukumba

karena terbatasnya pengetahuan guru terutama masalah pengelolaan dan pendekatan pengelolaan, baik yang sifatnya teoritis maupun pengalaman praktis, sudah barang tentu akan mengahambat perwujudan pengelolaan kelas dengan sebaik-baiknya. Kedua, peserta didik, dalam kegiatan pembelajaran Pendidikan Agama Islam di kelas kadangkala menjadi sumber munculnya masalah. Guru harus pandai-pandai mengatasi dan meminimalisasi gangguan yang timbul; dan ketiga, fasilitas yang ada merupakan faktor penting upaya guru memaksimalkan programnya, fasilitas yang kurang lengkap akan menjadi kendala yang berarti bagi seorang guru dalam beraktivitas. Namun, kendala secara spesifik yakni kurangnya fasilitas buku referensi bacaan peserta didik yang berhubungan dengan Pendidikan Agama Islam serta belum adanya dana subsidi pendidikan yang dapat diberikan kepada peserta didik untuk mengadakan kajian-kajian keislaman di luar jam efektif pembelajaran.

Kendala-kendala tersebut tentu saja mengharapkan kerjasama antara pihak sekolah dengan para pemerhati pendidikan untuk dukungan dana pengadaan buku referensi yang dibutuhkan sebagai bahan koleksi perpustakaan, serta kebijakan dari pihak yang berwenang dan yang terkait untuk penambahan alokasi waktu pembelajaran Pendidikan Agama Islam sebagaimana alokasi waktu yang ada pada mata pelajaran umum dan eksakta lainnya.

\section{Upaya Guru Mengatasi Hambatan dalam Pengelolaan Kelas pada Pembelajaran Pendidikan Agama Islam di SMP Negeri 39 Bulukumba}

Upaya-upaya yang dilakukan oleh guru PAI dalam mengatasi hambatan dalam strategi pengelolaan kelas dalam pembelajaran Pendidikan Agama Islam, antara lain sebagai berikut:

Pertama, Penguatan Kompetensi Guru PAI. Agar kualitas guru semakin meningkat dalam bidangnya setiap tahun guru mengikuti berbagai kegiatan dalam rangka meningkatkan potensinya seperti penataran, 
Andi Muhammad Asbar: Strategi Guru dalam Pengelolaan Kelas pada Pembelajaran Pendidikan Agama Islam di Smp Negeri 39 Bulukumba

seminar, lokakarya, dan pelatihan-pelatihan. Dengan adanya kegiatan tersebut merupakan strategi yang dilaksanakan untuk meningkatkan mutu pendidikan di SMP Negeri 39 Bulukumba sehingga dapat memperlancar kegiatan belajar mengajar di kelas, agar efektifitas belajar siswa dapat tercapai.

Kedua, melakukan kontrak pembelajaran di kelas. Untuk itu, diperlukan adanya pengelolaan kelas yang perumusannya berupa tata tertib yang dibicarakan bersama peserta didik dan kemudian disetujui oleh guru dan peserta didik itu sendiri. Jika siswa tidak ikut serta dilibatkan dalam pembuatan kontrak belajar atau tata tertib tersebut dikhawatirkan siswa akan bertindak seenaknya karena merasa tidak ikut membuat peraturan yang ada. Hal ini penting untuk mengatur peserta didik dan guru itu sendiri, yang disepakati dan dijalankan secara konsisten agar tercipta kelas yang efektif.

\section{E. Kesimpulan}

Setelah peneliti menelaah teori dan menganalisa hasil penelitian tentang strategi guru dalam pengelolaan kelas pada pembelajaran pendidikam agama Islam di SMP Negeri 39 Bulukumba, maka dapat diuraikan beberapa kesimpulkan, yakni: pertama, strategi pengelolaan kelas yang dilakukan oleh guru SMP Negeri 39 Bulukumba dalam melaksanakan pembelajaran yang efektif, efisien dan menyenangkan, itu tergambarkan dalam pengelolaan administrasi kelas, pengelolaan operatif kelas, pengaturan ruang kelas dan strategi pembelajaran. Kerjasama antara sekolah, guru dan siswa atau peserta didik, menjadi perhatian penting untuk ditingkatkan dalam meramu strategi pembelajaran di kelas khususnya, keaktifan dari Guru PAI SMP Negeri 39 Bulukumba tersebut. Dari penelitian ini, dapat dikatakan bahwa strategi pengelolaan kelas telah berjalan dengan baik, hanya saja komitmen bersama di lingkungan sekolah diperlukan untuk menjaga dan meningkatkan kualitas pembelajaran dapat tercipta di kelas. 
Andi Muhammad Asbar: Strategi Guru dalam Pengelolaan Kelas pada Pembelajaran Pendidikan Agama Islam di Smp Negeri 39 Bulukumba

Kedua, faktor pendukungnya dari strategi pengelolaan kelas dalam pembelajarn PAI di SMP Negeri 39 Bulukumba, antara lain; a. Kurikulum, hal ini penting menyangkut pelaksanaan pembelajaran yang sesuai dengan kurikulum nasional. dan b. Guru PAI, faktor guru disini sangat erat dengan kompetensi yang dimilikinya serta komitmen dalam menciptakan kondisi kelas yang baik. Sedangkan faktor penghambatnya, yakni: a. Hambatan tersebut bisa datang dari guru sendiri; b. Peserta didik dan c. Fasilitas. Artinya bahwa hambatan pasti akan ada ditemui oleh guru, makanya dibutuhkan menanganan untuk mengantisipasi atau mengatasi hal tersebut. Dan Ketiga, upaya yang dilakukan yakni: a. Penguatan kompetensi guru PAI; b. Melakukan kontrak pembelajaran dalam kelas. Hal ini penting untuk mengatur peserta didik dan guru itu sendiri, yang disepakati dan dijalankan secara konsisten agar tercipta kelas yang efektif serta tercipta suasana kelas yang kondusif dan mendukung pembelajaran disekolah utamanya dalam pembelajaran PAI.

Sebagai rekomendasi Perlu adanya pembinaan dan pemberian bimbingan/pelatihan secara berkelanjutan tentang strategi Pengelolaan Kelas bagi guru Pendidikan Agama Islam baik melalui Musyawarah Guru Mata Pelajaran (MGMP).

Jurnal Ilmiah Al QALAM, Vol. 12, No. 1, Januari-Juni 2018 
Andi Muhammad Asbar: Strategi Guru dalam Pengelolaan Kelas pada Pembelajaran Pendidikan Agama Islam di Smp Negeri 39 Bulukumba

\section{Daftar Pustaka}

Arikunto, Suharsimi. Pengelolaan Kelas dan Siswa, Sebuah Pendekatan Evaluatif, Jakarta: Rajawali, 1992.

Asrohah, Hanun. Sejarah Pendidikan Islam. Cet. I: Jakarta: Logos Wacana Ilmu, 1999.

Daradjat, Zakiyah. Ilmu Pendidikan Islam, Jakarta: PT. Bumi Aksara, 2009.

Departemen Pendidikan Nasional, Standar Kompetensi Mata Pelajaran Pendidikan Agama Islam SMP dan MTS, Jakarta: Pusat Kurikulum, Balitbang Depdiknas, 2003.

Departemen Agama RI, al-Qur'anul Karim Terjemahnya dan Tajwid Berwarna Disertai Tafsir Ringkas Ibnu Katsir. Jakarta: Jabal Raudhotul Jannah, 2009.

Djamarah, Syaiful Bahri dan Aswan Zain, Strategi Belajar Mengajar, Jakarta: PT. Rineka Cipta, 2006.

Getteng, Abd Rahman. Menuju Guru yang Profesional dan Beretika. Cet. III; Yogyakarta: Graha Guru, 2008.

Herlina, Guru Pendidikan Agama Islam pada kelas VIII/A-G di SMP Negeri 39 Bulukumba, Wawancara, Bulukumba, 15 Maret 2016.

Kamaruddin, Guru Pendidikan Agama Islam pada kelas IX/A-G di SMP Negeri 39 Bulukumba, Wawancara, Bulukumba, 07 Maret 2016.

Khaeruddin, Ilmu Pendidikan Islam: Mendesain Insan yang Hakiki dan Mengintip dalam Sejarahnya. Cet. II; Makassar: Yayasan Pendidikan Fatiya, 2004.

Madjid, Nurcholish. Masyarakat Religius. Cet. III; Jakarta: Paramadina, 2005.

Majid, Abdul dan Dian Andayani, Pendidikan Agama Islam Berbasis Kompetensi, Bandung: PT Rosdakarya, 2005.

Moleong, Lexy J. Metodologi Penelitian Kualitatif, Cet. XXVIII; Bandung: Remaja Rosdakarya, 2006.

Muhaimin, Wacana Pengembangan Pendidikan Islam, Yogyakarta: Pustaka Pelajar, 2003.

Muhaimin, dkk, Paradigma Pendidikan Islam, Cet. V; Bandung: PT. Rosdakarya, 2012.

Muhajir, Noeng. Metodologi Penelitian Kualitatif Yogyakarta: Rake Sarasin, 1996.

Pidarta, Made. Pengelolaan Kelas, Surabaya: Usaha Nasional, 1970.

Jurnal Ilmiah Al QALAM, Vol. 12, No. 1, Januari-Juni 2018 
Andi Muhammad Asbar: Strategi Guru dalam Pengelolaan Kelas pada Pembelajaran Pendidikan Agama Islam di Smp Negeri 39 Bulukumba

Shihab, M. Quraish. Membumikan al-Qur'an: Fungsi dan Peran Wahyu dalam Kehidupan Masyarakat. Bandung: Mizan, 1992.

Sanjaya, Wina. Strategi Pembelajaran Berorientasi Standar Proses Pendidikan, Jakarta: Kencana, 2007.

Tirtarahardja, Umar dan S. L. La Sulo, Pengantar Pendidikan Edisi Revisi. Cet. II; Jakarta: Rineka Cipta, 2005.

Undang-Undang Republik Indonesia No. 20 Tahun 2003 tentang Sistem Pendidikan Nasional. Cet. I; Jakarta: Sinar Grafika, 2003. 